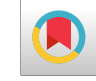

\title{
Investigation of Fever Control in Febrile Patients: A Narrative Review
}

\author{
Davood Hekmatpou ${ }^{1,{ }^{*}}$ and Mansoreh Karimi Kia ${ }^{1}$ \\ ${ }^{1}$ Nursing and Midwifery Faculty, Arak University of Medical Sciences, Arak, Iran \\ "Corresponding author: Associate Professor, Ph.D in Nursing, Nursing and Midwifery Faculty, Arak University of Medical Sciences, Basij Sq., Payambar-e-Azam Educational \\ Complex, Arak, Iran. Tel: +98-9181616539, Fax: +98-8634173528, Email: dr_hekmat@arakmu.ac.ir
}

Received 2018 October 09; Accepted 2018 October 16.

\begin{abstract}
Context: Fever is one of the most common problems in patients. There are a variety of fever control interventions with different levels of efficacy and side effects across patients, especially among critically ill individuals. In this regard, the current review study was conducted to examine the evidence regarding the nursing interventions used to control fever.

Evidence Acquisition: For the current study, the articles on fever control methods were searched throughout several databases including SID, Irandoc, Google Scholar, PubMed, Medline, Scopus, Cochrane Library, and ScienceDirect. The search process was accomplished using the following keywords: "management of fever", hyperthermia", and "nursing intervention". The electronic search was performed without any time limit. The exclusion criteria were the duplicate and incomplete studies, animal studies, the ones without clear statistical analysis, and those with a sample size of $<30$ subjects (due to low statistical power).

Results: The electronic search resulted in the inclusion of 22 articles. In most of the studies, acetaminophen was introduced as the first choice of therapists to control fever. The adoption of physical methods to manage fever varied across different centers depending on the available facilities and hospital routines.

Conclusions: As the findings of the reviewed studies indicated, pharmaceutical and physical methods to manage fever should be selected according to patient's conditions. It is recommended that a combination of physical and pharmaceutical interventions for this purpose be utilized. It is also suggested that proper protocols be presented for the appropriate treatment and management of fever under different conditions.
\end{abstract}

Keywords: Febrile Patients, Fever, Care, Sponge Bath

\section{Context}

Fever is defined as a rise in the body temperature above the normal range and is associated with an increase in the hypothalamic set point (1). Based on the Infectious Diseases Society of America, a temperature of above $38.3^{\circ} \mathrm{C}$ is considered as a fever and requires the clinical examination of the patient. Fever is caused by both infectious and non-infectious agents (2). Recent evidence suggests that fever and hyperthermia have detrimental effects, particularly on patients, and are associated with increased mortality rate, multiplied risk of severe disabilities, and prolonged hospital stay (3).

Fever leads to the reduction of cardiac output and enhancement of metabolic demand, oxygen consumption, and serum lactate levels. It also results in vasoconstriction, tissue damage, restlessness, and seizure in children. The emergence of fever necessitates the administration of more diagnostic tests and therapeutic measures, and prolongs hospital stay. This enhances the cost of medical therapies and exposes the patient to unnecessary invasive treatments, and even improper use of antibiotics (4).

Fever should be controlled with medical therapy or physical methods, especially in critically ill patients, due to the possibility of hemodynamic instability in such patients (5). Therefore, the management of febrile patients requires proper, specific, and pertinent care principles. However, little is known about the best available method to reduce fever. Despite the lack of sufficient evidence in the literature, there are multiple practical techniques commonly used to reduce body temperature in clinical practices (6). Pharmaceutical interventions to reduce body temperature can have several adverse effects such as hypotension, gastrointestinal bleeding, hepatic and nephrotic toxicity, and prolonged intensive care unit (ICU) stay (7).

However, the employment of physical methods to control fever is controversial due to peripheral arterial stimulation and contraction, sympathetic nervous system activation, and patient discomfort (8). There are several methods for surface cooling, the most commonly used of which 
include cold or hot compress, warm or lukewarm bath, hypothermia blankets, air conditioning, and elevation of environmental temperature (9). However, there is no consensus among the experts on the most efficient and safest strategy to control body temperature (10). Due to the problems that occur following the fever, the current review study aimed at investigating the evidence related to the efficient nursing interventions of fever control.

\section{Evidence Acquisition}

The current review study included the articles examining fever control nursing interventions. For this purpose, the articles related to the subject of interest were searched in several national and international databases, including SID, Irandoc, Google Scholar, PubMed, Medline, Scopus, Cochrane Library, and ScienceDirect. Moreover, the reference lists of the retrieved articles were reviewed to identify more relevant studies. The search was performed based on the following keywords: "management of fever", hyperthermia", and "nursing intervention".

All papers using different methods to reduce fever and those employing a control group or comparing different treatments were included in the study. The electronic search was carried out with no time limits. On the other hand, the duplicate or incomplete studies, as well as those that examined animals, had unclear statistics, was conducted on a sample size of $<30$ subjects (due to low statistical power) were excluded from the review process (Figure 1).

\section{Results}

A total of 66 studies were found, 1, 8, 8, 10, 14, 15, 15 , and 20 cases of which were retrieved from Cochrane Library, SID, Medline, Irandoc, PubMed, ScienceDirect, Google Scholar, and Scopus, respectively and 25 were excluded due to duplication. Out of these 66 papers, 2, 11, and 11 cases were excluded from the study due to inaccessibility to the full text, improper statistical analysis, and a sample size of $<30$ cases (due to low statistical power), respectively. In addition, 20 articles were excluded from the review process due to investigating specific infections such as Crimean-Congo fever, typhoid, urinary tract infections, the Kawasaki syndrome, and neutropenia, as well as antibiotic administration to control fever. Finally, 22 articles were entered into the analysis (PRISMA flowchart).

Out of the 22 papers, 15 cases were clinical trials, investigating the pharmaceutical $(n=6)$ and non-pharmaceutical $(n=9)$ treatments to control fever. Furthermore, three cases were review studies, and the other four articles were

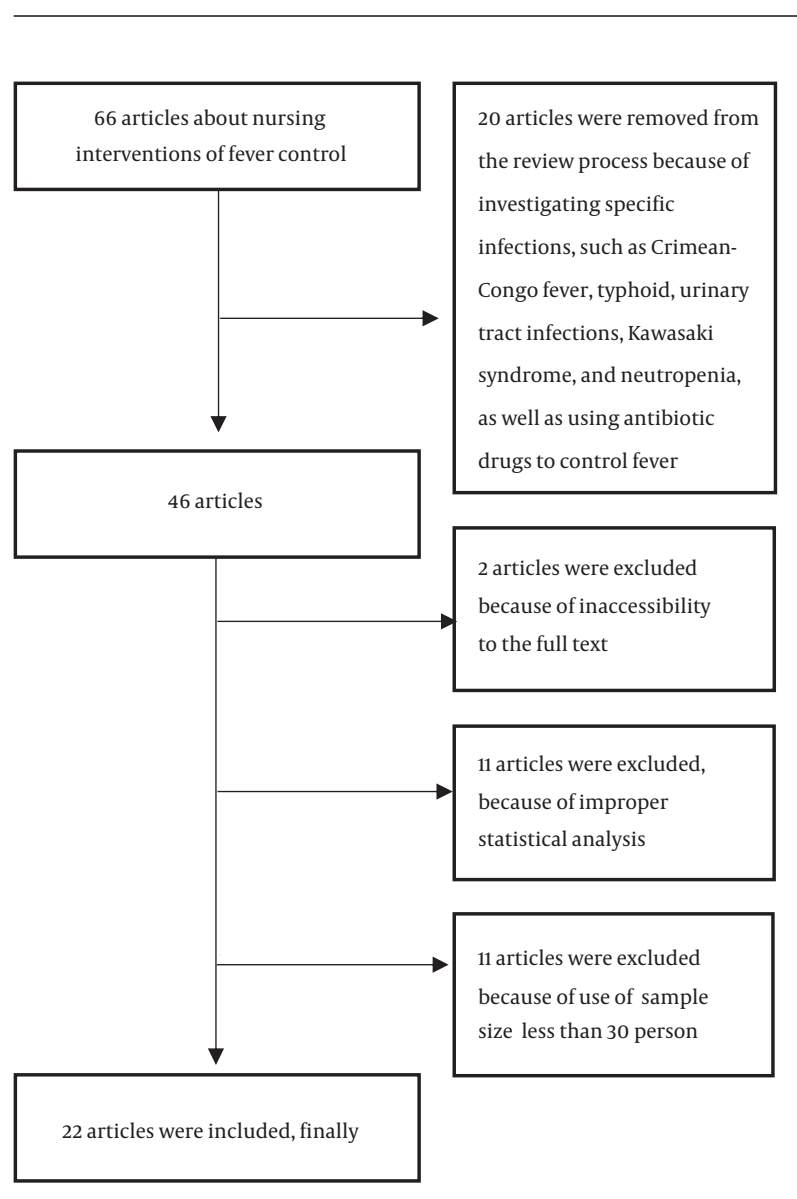

Figure 1. PRISMA flowchart of search strategy and selection process

based on phone call or online surveys and questioning the nurses about the methods to control the fever.

The use of antipyretics was reported as the most commonly used method to reduce fever in several studies. Surface cooling techniques, such as hyperthermia blankets, lukewarm bath, and ice packs, were also used alone or in combination with pharmaceutical methods. The application of pharmacotherapy to reduce fever had a number of unwanted side effects including hemodynamic disorders such as hypotension, hepatic and renal dysfunction, as well as water and sodium retention. Physical methods to control fever also caused complications such as chills, vasoconstriction, and restlessness. In the cases that the main objective was to reduce fever, a range of treatments was introduced without a standard method (11). Since each method had its own advantages and disadvantages, further investigations seem necessary in this regard.

In the articles investigating the pharmaceutical methods of fever control, oral and injectable acetaminophen and ibuprofen were reported as the most commonly used 
medications. Overall, pharmaceutical treatments were effective in controlling fever, and the results indicated that the combination of medications was more effective than a single-drug therapy (Table 1). As mentioned earlier, the use of medications such as acetaminophen is one of the most common and well-known methods to control fever. However, pharmacotherapy is often associated with a delay of several hours to achieve the desired effect. In addition, in severe cases, even higher doses of the drug may not provide the desired reaction (12).

When attempting to reduce the temperature through different methods, care should be taken not to exacerbate the underlying disease of the patient or cause a new illness in the patient (13). The application of pharmaceutical methods to reduce fever in the patients with hypovolemia, or underlying hepatic or renal diseases can cause or aggravate liver and kidney dysfunction (14). Therefore, the probability of creating problems is another limitation of pharmaceutical methods (12). In a study, the cost of fever treatment with acetaminophen for patients admitted to the ICU was estimated US $\$ 10000$ - 29000 per year (9).

No studies estimated the costs associated with the physical methods of temperature reduction. Lee et al. reported that the application of non-steroidal antiinflammatory drugs or acetaminophen to control fever increased the mortality rate in infected patients over a 28 day period. On the other hand, there was no increase in the mortality rate among the patients receiving nonpharmaceutical treatment for fever reduction (5). The existence of such constraints suggests that research on the use of other methods to reduce body temperature should be also considered. It is essential to consider other complications and underlying diseases when prescribing medications to control fever.

The other alternative to control fever is to use physical methods such as airflow and water-flow, tepid sponging, ice packs, hypothermia blankets, and intravascular methods. Table 2 summarizes the studies that investigated physical interventions and compared the pharmaceutical methods with the physical interventions. The results of these studies showed that physical methods were one of the effective methods to control fever, leading to better outcomes if combined with other methods such as tepid sponging and airflow. In addition, the application of intravascular cooling systems, especially in central veins, was very effective on controlling fever. The combination of physical methods with pharmaceutical therapies improved the efficacy of fever management. In intravascular methods, by means of an intravascular cooling device, cool saline flows in balloons located in the blood vessels. In this method, saline lowers the temperature without a direct contact with the blood. Although these tools are gen- erally designed to create hypothermia, they are sometimes used to treat fever (7).

The findings of the three review studies reveled that physical methods were effective in controlling fever; however, they also had side effects for the patients (Table 3 ). Body temperature reduction is not easy and is associated with a number of risks (23). This underscores the necessity of identifying a safe method. Physical methods are among the interventions that can be adopted to control fever (14). Nurses have a key role in the implementation of these interventions as decision makers and initiators of these methods.

The history of using physical methods to reduce the temperature may date back to Florence Nightingale (1820 - 1910) (27). Contrary to the historical records, these methods still need further investigation. Prior to 2000, there was no comprehensive study comparing the physical methods of temperature reduction, such as tepid sponging or lukewarm water bath, especially in the ICU (28). However, according to the literature review, since the last decade, there is a growing interest in the investigation and comparison of different methods of reducing body temperature to identify a more effective, convenient, easily accessible, and low-cost method.

Rapid reduction of the temperature leads to severe reactions of the autonomic nervous system, which results in shivering (29). Chills are the most important complications caused by the application of physical interventions to reduce the temperature. Therefore, this condition results in a three- or five-fold increase in the metabolic demand (27). Shah et al. demonstrated that temperature dropping by $0.62^{\circ} \mathrm{C} / \mathrm{h}$ caused shivering in all patients (28).

Autonomic responses may also present in the form of such complications as restlessness, peripheral vascular contraction, and even coronary artery contractions (27). In addition, at the time of cooling by means of physical methods, oxygen consumption is increased up to $57.6 \%$ and blood pressure is raised by $15 \%$ (30). The application of physical methods to cooldown the body temperature also increases the levels of epinephrine and norepinephrine (31). As a result, the comfort of the patient, identification of the causative agents of fever, prevention of complications such as shivering, which exacerbate patient condition, should be prioritized.

In four articles, the data were collected by phone call, online interviews, or surveys of nurses about the methods of fever control. These studies showed that most of the centers did not have comprehensive guidelines to control fever, and that the most commonly used interventions were acetaminophen use. 


\begin{tabular}{|c|c|c|c|c|}
\hline Author & Year & Sample Size & Method & Result \\
\hline Greenberg et al. (15) & 2010 & 166 febrile patients admitted to ICU & $\begin{array}{l}\text { Patients were randomly divided into two } \\
\text { groups. The first group was treated with } \\
\text { acetaminophen injection, and the } \\
\text { second group received no fever } \\
\text { treatment. }\end{array}$ & $\begin{array}{l}\text { The acetaminophen group showed a } \\
\text { significant decrease in temperature and } \\
\text { increase in speed of fever reduction. }\end{array}$ \\
\hline Peacock et al. (16) & 2011 & 5 febrile patients with internal problems & $\begin{array}{l}\text { Patients were randomly divided into two } \\
\text { groups. The first group was given } 1 \mathrm{~g} \text { of } \\
\text { intravenous acetaminophen, and the } \\
\text { second group received } 1 \mathrm{~g} \text { oral } \\
\text { acetaminophen every } 6 \mathrm{~h} \text {. }\end{array}$ & $\begin{array}{l}\text { Both methods of acetaminophen } \\
\text { administration were effective and safe in } \\
\text { reducing fever. }\end{array}$ \\
\hline Mullins et al. (17) & 2011 & $\begin{array}{l}79 \text { patients with a high temperature } \\
\left(38^{\circ} \mathrm{C}\right) \text { admitted to neurosurgery ICU }\end{array}$ & $\begin{array}{l}\text { Patients were randomly divided into } \\
\text { three groups. The first group was treated } \\
\text { with } 975 \mathrm{mg} \text { of acetaminophen, the } \\
\text { second group with } 800 \mathrm{mg} \text { ibuprofen, } \\
\text { and the third group with both } \\
\text { acetaminophen and ibuprofen. }\end{array}$ & $\begin{array}{l}\text { In all three groups, body temperature } \\
\text { was reduced in } 6 \mathrm{~h} \text {. The combination of } \\
\text { acetaminophen and ibuprofen was } \\
\text { significantly more effective on } \\
\text { controlling fever than the other two } \\
\text { methods. }\end{array}$ \\
\hline Promes et al. (18) & 2011 & $\begin{array}{l}61 \text { febrile patients with grade II or III } \\
\text { burns }\end{array}$ & $\begin{array}{l}\text { Patients were randomly divided into two } \\
\text { groups. The first group received } 800 \mathrm{mg} \\
\text { intravenous ibuprofen, and the second } \\
\text { group received placebo every } 6 \mathrm{~h} \text { for } 5 \mathrm{~d} \text {. }\end{array}$ & $\begin{array}{l}\text { Fever significantly reduced in the } \\
\text { ibuprofen group. This amount of } \\
\text { ibuprofen can be tolerated without any } \\
\text { special side effects. }\end{array}$ \\
\hline Kokki (19) & 2010 & $\begin{array}{l}90 \text { children in the age range of } 6 \mathrm{mn} \text { to } 6 \\
\mathrm{yr} \text { with a body temperature of above } \\
38.8^{\circ} \mathrm{C}\end{array}$ & $\begin{array}{l}\text { Patients were randomly divided into } \\
\text { three groups. The first group received } \\
\text { ketoprofen }(0.5 \mathrm{mg} / \mathrm{kg}) \text {, the second } \\
\text { group acetaminophen }(20 \mathrm{mg} / \mathrm{kg}) \text {, and } \\
\text { the third group ibuprofen syrup ( } 5 \\
\mathrm{mg} / \mathrm{kg} \text { ) every } 6 \text { h orally. }\end{array}$ & $\begin{array}{l}\text { Fever effectively reduced in all three } \\
\text { groups. Ketoprofen syrup had no } \\
\text { harmful effects, compared with the other } \\
\text { two drugs. }\end{array}$ \\
\hline Young et al. (7) & 2015 & 700 febrile patients admitted to ICU & $\begin{array}{l}\text { Patients with a high temperature of } 38^{\circ} \mathrm{C} \\
\text { were randomly divided into two groups. } \\
\text { The first group received } 1 \mathrm{~g} \\
\text { intraperitoneal acetaminophen every } 6 \\
\text { h, and the second group } 100 \mathrm{~mL} \text { of } 5 \% \\
\text { dextrose water every } 6 \mathrm{~h} \text {. }\end{array}$ & $\begin{array}{l}\text { The acetaminophen recipient group had } \\
\text { a decrease in the temperature at the } \\
\text { maximum daily temperature and } \\
\text { average daily temperature, compared } \\
\text { with the placebo group. }\end{array}$ \\
\hline
\end{tabular}

\section{Discussion}

Fever control interventions include the application of medications (e. g. non-steroidal anti-inflammatory drugs and acetaminophen), as well as surface and intravascular cooling mechanisms. However, these alternatives can have their own side effects. Nonsteroidal anti-inflammatory drugs can be very effective in reducing fever; however, they can cause renal dysfunction. The consumption of $4 \mathrm{mg}$ acetaminophen per 24 hours is associated with transaminitis. Therefore, daily acetaminophen dosage should be calculated. Analgesics, which are the combinations of opiates and acetaminophen, are often ignored in the calculation. Acetaminophen injection is also very helpful to control fever; although it is costly (38).

The conventional and well-known methods of using tepid sponging or lukewarm water bath can significantly reduce the body temperature often at a relatively short time due to the direct contact with the patient body in a prolonged and continuous manner (39). However, it usually requires access to the specific parts of the patient's body; in addition, it may stimulate the thermoregulation mechanism leading to skin temperature reduction by vasoconstriction. Moreover, these methods not only fail to reduce the body temperature uniformly, but also increase the workload of the nurses in the ward (31).

It takes 45 - 60 minutes to prepare the equipment for lukewarm water bath, while the minimum time to administer acetaminophen is around 5 - 10 minutes. Therefore, the administration of acetaminophen saves nurses 50 minutes (40). However, considering the risks of acetaminophen consumption including increased mortality (5), these methods should be employed with precaution. In physical methods, it is recommended that the patients' conditions be considered and a combination of methods be employed.

Chan et al. reported the most common physical methods of reducing fever as using ice in areas rich in blood vessels, cooling blankets, and fans (27). In the infectious diseases book, written by Mandell (2009), the application of a fan is introduced as one of the physical strategies to reduce fever (41). The results of most of the reviewed studies were indicative of the high efficacy of airflow; moreover, this technique was reported to have low complications to control fever and reduce both the surface and core temperatures (20).

The review of the common fever control treatments in 


\begin{tabular}{|c|c|c|c|c|}
\hline Author & Year & Sample Size & Method & Result \\
\hline Creechan et al. (20) & 2001 & $\begin{array}{l}41 \text { patients from } \\
\text { three ICU in two } \\
\text { groups }\end{array}$ & $\begin{array}{l}\text { A group was exposed to airflow, and the } \\
\text { other group to water-flow. }\end{array}$ & $\begin{array}{l}\text { The rates of temperature reduction were } 0.377^{\circ} \mathrm{C} \text { and } \\
0.163^{\circ} \mathrm{C} \text { per hour in the airflow and water-flow groups, } \\
\text { respectively. The success rates of reaching } 38^{\circ} \mathrm{C} \text { or less } \\
\text { were } 75 \% \text { and } 47 \% \text { in the airflow and water-flow } \\
\text { groups, respectively. }\end{array}$ \\
\hline Mayer et al. (21) & 2001 & $\begin{array}{l}220 \text { febrile patients } \\
\text { in NICU }\end{array}$ & $\begin{array}{l}220 \text { febrile patients (above } 38.3 \text { yrs) were } \\
\text { randomly divided into two groups. In one } \\
\text { group, } 650 \text { mg acetaminophen was } \\
\text { administered every four h; in the second } \\
\text { group, acetaminophen was used in } \\
\text { conjunction with airflow. }\end{array}$ & $\begin{array}{l}\text { The effect of airflow vests on reducing patient body } \\
\text { temperature was investigated. The response to } \\
\text { treatment in the combined group was higher than } \\
\text { that of the drug alone ( } 53 \% \text { versus } 42 \% \text { ), but this } \\
\text { difference was not statistically significant. }\end{array}$ \\
\hline Price et al. (22) & 2003 & $\begin{array}{l}160 \text { patients with } \\
\text { fever }\end{array}$ & $\begin{array}{l}\text { At baseline, patients were randomly } \\
\text { divided into two groups of } 80 \text { cases. The } \\
\text { case group received } 1 \mathrm{~g} \text { paracetamol. After } \\
\text { an hour, the central temperature of both } \\
\text { groups were measured, those who still had } \\
\text { high temperature entered the second } \\
\text { stage and underwent physical therapy for } \\
\text { fever using airflow, lukewarm water bath, } \\
\text { ice packs, and hyperthermia blankets. } \\
\text { After } 24 \text { h, the body temperature was } \\
\text { measured. }\end{array}$ & $\begin{array}{l}\text { The results of the second phase of the study showed } \\
\text { that the fan was not effective in reducing the } \\
\text { temperature in the two groups that received } \\
\text { paracetamol. When taken with paracetamol, the } \\
\text { lukewarm body bath was effective in keeping the } \\
\text { body temperature low up to } 24 \text { h in } 60 \% \text { of patients. } \\
\text { Also, the use of ice in patients that did not receive } \\
\text { paracetamol was ineffective. Due to the technical } \\
\text { problems in the blankets, their effect was not reliable. }\end{array}$ \\
\hline Gozzoli et al. (9) & 2004 & $\begin{array}{l}30 \text { febrile patients in } \\
\text { ICU }\end{array}$ & $\begin{array}{l}\text { It was observed that the three methods of } \\
\text { the administration of metamizole and } \\
\text { paracetamol, and a cooling method (water } \\
\text { bath) could reduce fever. In the lukewarm } \\
\text { water bath group, wet clothes were } \\
\text { replaced every } 30 \text { minutes. The rectal } \\
\text { temperature was measured with a digital } \\
\text { thermometer. }\end{array}$ & $\begin{array}{l}\text { In all three groups, body temperature decreased } \\
\text { significantly during the first } 2 \mathrm{~h} \text {, and there was no } \\
\text { significant difference between the three groups after } \\
4 \mathrm{~h} \text { (temperature decreased from } 0.5^{\circ} \mathrm{C} \text { to } 0.9^{\circ} \mathrm{C} \text { ). In } \\
\text { the cooling group, the surface temperature of the } \\
\text { body reduced more than } 1^{\circ} \mathrm{C} \text {. }\end{array}$ \\
\hline $\begin{array}{l}\text { Hoedemaeker et al. } \\
\text { (23) }\end{array}$ & 2007 & $\begin{array}{l}50 \text { patients admitted } \\
\text { to ICU }\end{array}$ & $\begin{array}{l}\text { In the first group, the Ringer serum was } \\
\text { injected at } 4^{\circ} \mathrm{C} \text { with a dose of } 30 \mathrm{~mL} / \mathrm{kg} \text {. The } \\
\text { second group was subjected to water-flow } \\
\text { circulation in special clothes under and } \\
\text { around the patient's body. The third group } \\
\text { was managed with the airflow of } 10^{\circ} \mathrm{C} \text { at a } \\
\text { rate of } 28-32 \mathrm{cfm} \text { around the patient's } \\
\text { body. In the fourth group, a cooling gel } \\
\text { was used with a cloth pad. In the last } \\
\text { group, fluid infusion was performed in the } \\
\text { inferior vena cava via femoral vein. }\end{array}$ & $\begin{array}{l}\text { The reduction of body temperature occurred } \\
\text { effectively in the method of cooling blankets with } \\
\text { flow of water, ice, pad, or cooling gel, intravascular } \\
\text { temperature exchange systems, ice bags, and } \\
\text { air-cooled blankets, respectively. The intravascular } \\
\text { heat exchange systems reduced temperature at more } \\
\text { a reliable speed than other systems. }\end{array}$ \\
\hline $\begin{array}{l}\text { Mohammed and } \\
\text { Ahmed (24) }\end{array}$ & 2012 & $\begin{array}{l}45 \text { patients referring } \\
\text { to the Egyptian } \\
\text { tropical hospital } \\
\text { with typhoid fever }\end{array}$ & $\begin{array}{l}\text { Patients were divided into three groups } \\
\text { and placed under water bath with cold } \\
\text { water and vinegar or cold water with } \\
\text { vinegar }\end{array}$ & $\begin{array}{l}\text { All three methods effectively reduced the body } \\
\text { temperature of febrile patients. Water bath with } \\
\text { vinegar was more successful in controlling fever than } \\
\text { the other two methods. This method was } \\
\text { recommended for controlling fever. }\end{array}$ \\
\hline Zeighami et al. (25) & 2013 & $\begin{array}{l}72 \text { febrile patients } \\
\text { admitted to ICU }\end{array}$ & $\begin{array}{l}72 \text { subjects were selected by convenient } \\
\text { sampling method and based on the } \\
\text { ventilation condition; the samples were } \\
\text { randomly assigned into four groups of } \\
\text { control, water bath, airflow, and combined } \\
\text { method. Samples were under treatment } \\
\text { for } 4 \mathrm{~h} \text {. }\end{array}$ & $\begin{array}{l}\text { Both active water bath and cooling could reduce } \\
\text { body temperature within } 3 \text { h. Although water bath } \\
\text { was effective in reducing body temperature, the } \\
\text { active cooling method was more effective than water } \\
\text { bath to control the fever. }\end{array}$ \\
\hline $\begin{array}{l}\text { Zaaqoq and Yende } \\
\text { (26) }\end{array}$ & 2013 & $\begin{array}{l}200 \text { patients } \\
\text { admitted to seven } \\
\text { ICUs in France }\end{array}$ & $\begin{array}{l}\text { Patients were divided into two groups (i e, } \\
\text { with physical intervention and without } \\
\text { physical intervention). }\end{array}$ & $\begin{array}{l}\text { Physical intervention to reduce the fever was safe. } \\
\text { Fever effectively reduced in this group. The use of an } \\
\text { external cooling method reduced the need for } \\
\text { vasopressors and early mortality in patients with } \\
\text { septic shock. }\end{array}$ \\
\hline $\begin{array}{l}\text { Hekmatpou et al. } \\
(4)\end{array}$ & 2018 & $\begin{array}{l}60 \text { febrile patients } \\
\text { admitted to ICU }\end{array}$ & $\begin{array}{l}64 \text { febrile patients were randomly divided } \\
\text { into two groups of ice pack and water bath } \\
\text { treatments. The intervention groups were } \\
\text { under treatment for } 3 \mathrm{~h} \text {. }\end{array}$ & $\begin{array}{l}\text { Both groups of patients experienced a decrease in } \\
\text { body temperature after } 3 \mathrm{~h} \text { of intervention, but there } \\
\text { was no significant difference between the two } \\
\text { intervention groups. }\end{array}$ \\
\hline
\end{tabular}

some medical centers revealed that there was no clear protocol to manage fever; therefore, different interventions were used in various centers to this end (2011). Launey et al., stated that the measurement of the benefits and detri- ments of fever control interventions in patients admitted to ICUs was very complicated. Moreover, the benefits of the commonly used fever treatments are not confirmed by the clinical data yet. Therefore, it is required to perform a 


\begin{tabular}{|c|c|c|c|c|}
\hline Author & Year & Sample Size & Method & Result \\
\hline $\begin{array}{l}\text { Dalal and Zhukovsky } \\
\text { (32) }\end{array}$ & 2006 & Review article & $\begin{array}{l}\text { Review of } 77 \text { articles } \\
\text { about fever }\end{array}$ & $\begin{array}{l}\text { Non-specialized interventions to reduce the fever mentioned } \\
\text { in the articles included the enhancement of fluid intake, } \\
\text { removal of excess clothing, body wash with wet gauzes, } \\
\text { cooling the environment using a fan. In the fever control } \\
\text { methods, the priorities are creating comfort and convenience } \\
\text { for the patient and controlling the causes of the fever. }\end{array}$ \\
\hline Launey et al. (33) & 2011 & Reviewing 64 articles & $\begin{array}{l}\text { Examination of the } \\
\text { advantages or } \\
\text { disadvantages of } \\
\text { controlling fever in the } \\
\text { infected patients in ICU }\end{array}$ & $\begin{array}{l}\text { Prior to using the medical and physical treatments for fever } \\
\text { control in the ICU, the risks and potential benefits of the } \\
\text { techniques should be taken into account. Physical methods to } \\
\text { control fever have controversial effects on patients. Increased } \\
\text { sympathetic activity, peripheral vascular contraction, } \\
\text { shivering, increased body temperature, and increased oxygen } \\
\text { consumption were among the adverse effects of physical fever } \\
\text { control methods. }\end{array}$ \\
\hline
\end{tabular}

Table 4. Review of the Articles on the Nurse's Survey of Fever Control Methods

\begin{tabular}{llll}
\hline Author & Year & Sample Size & Method \\
\hline Johnston et al. (35) & 2006 & $\begin{array}{l}\text { 33 adult Neurosurgery } \\
\text { Centers in England and } \\
\text { Ireland }\end{array}$ & $\begin{array}{l}\text { The head nurses of these } \\
\text { centers were contacted } \\
\text { by telephone to be } \\
\text { interviewed about the } \\
\text { methods of fever } \\
\text { control. }\end{array}$ \\
& &
\end{tabular}

\begin{tabular}{|c|c|c|}
\hline Scaravilli et al. (34) & 2011 & $\begin{array}{l}\text { Sending } 588 \text { emails to } \\
\text { the nurses and doctors } \\
\text { in ICUs }\end{array}$ \\
\hline $\begin{array}{l}\text { Thompson and Kagan } \\
\text { (36) }\end{array}$ & 2011 & $\begin{array}{l}328 \text { nurses working in } \\
\text { neurosurgery } \\
\text { department }\end{array}$ \\
\hline
\end{tabular}

$\begin{array}{ll}2013 \quad \text { Niven et al. (37) } & \text { 139 Health Care } \\ & \text { Departments from } 23\end{array}$

A scenario-based online survey was conducted. Nurses and doctors of the intensive care society in Australia and New Zealand were asked about fever control measurements.

A survey was conducted on 328 nurses working in the Neurosurgery Department of US hospitals on fever control protocol in their workplace.

A survey was conducted on the nurses working in 139 ICUs of 23 countries about the nursing care methods of fever control.
Result

6 centers announced that they had a clear protocol to reduce fever. The first line of fever treatment in 13 centers was the administration of acetaminophen. Furthermore, cold fluid administration (either orally or via intravascularly), sponging, water-flow cooling blankets, and airflow cooling blankets were used in 1, 2, 6, and 9 units, respectively. In general, there was no agreement in fever control methods. Therefore, the preparation of a guideline based on the clinical trials was recommended.

The participants replied back 447 emails. A total of 308 nurses and 137 doctors responded to the febrile illness scenario. The first-line treatment for fever was the combination of acetaminophen and surface body cooling techniques. The second-line of interventions involved adding severe physical cooling methods. Significant differences were observed in the reported management of fever.

Only $19 \%$ of nurses reported to have a clear protocol to control fever in their hospitals. All protocols included the use of acetaminophen, although its dose and frequency varied. Different physical interventions were reported to control fever in various hospitals, the most common of which were icepacks, cooling blankets, and lukewarm water bath.

In order to control fever, in most of the cases, acetaminophen, infection workup, physical methods, and non-steroid drugs were used, respectively. well-designed, prospective, randomized trial to investigate the advantages and disadvantages of fever control methods (33).

\subsection{Conclusions}

Based on the findings of the reviewed studies, the most common method to reduce fever is to use antipyretics and acetaminophen. These drugs should be taken with caution in patients with hepatic and renal dysfunctions. In addition, physical methods are commonly employed to reduce fever and hyperthermia; however, the application of these methods is controversial since they tend to activate the sympathetic nerve system and lead to peripheral vascular contraction and shivering. 
Furthermore, the body temperature regulation mechanisms limit the surface cooling attempts made to reduce the core temperature since they help body maintain a high temperature. Shivering due to the employment of physical methods to control fever increases the oxygen consumption and is potentially harmful; therefore, it is necessary to calm down the patient by medications reducing the muscle strength.

Other alternatives, such as airflow and waterflow cooling blankets reduce the temperature effectively; however, they are costly. Other methods, such as lukewarm water bath, tepid sponging, ice packs, and fans, are also useful and cost-effective. Healthcare providers can adopt the best physical technique with regard to the available facilities and clinical conditions of the patients. The best way to reduce the body temperature is to utilize core body temperature heat exchange catheters; however, the catheter insertion is associated with some risks for the patients.

According to these concerns, healthcare providers should decide on the most efficient fever control method by considering the advantages and disadvantages of each alternative. Moreover, the combination of drug and physical interventions is also recommended. Due to the lack of a standard protocol to control fever in most of the treatment centers, it is suggested to provide protocols for different patients in various conditions. This requires the implementation of further extensive investigations about the efficacy and complications of various fever control methods in different individuals.

\section{Acknowledgments}

Authors are grateful for the project support from Arak University of Medical Sciences.

\section{Footnote}

Authors' Contribution: Davood Hekmatpou: Conception and design, introduction, data collection, and statistical analysis, manuscript writing, and final approval of the manuscript; Mansoreh Karimi Kia: Introduction, data collection, manuscript writing, and final approval of the manuscript.

\section{References}

1. Nakajima Y. Controversies in the temperature management of critically ill patients. J Anesth. 2016;30(5):873-83. doi: 10.1007/s00540-0162200-7. [PubMed: 27351982].

2. O'Grady NP, Barie PS, Bartlett JG, Bleck T, Carroll K, Kalil AC, et al. Guidelines for evaluation of new fever in critically ill adult patients: 2008 update from the American College of Critical Care Medicine and the Infectious Diseases Society of America. Crit Care Med.2008;36(4):133049. doi: 10.1097/CCM.ob013e318169eda9. [PubMed: 18379262].
3. Rockett H, Thompson HJ, Blissitt PA. Fever management practices of neuroscience nurses: What has changed? J Neurosci Nurs. 2015;47(2):66-75. doi: 10.1097/JNN.0000000000000118. [PubMed: 25634653].

4. Hekmatpou D, Karimi Kia M, Rahzani K. Comparing the effectiveness of sponge cooling and ice packs methods on controlling the patients' fever in intensive care units: A randomized clinical trial. Prog Palliative Care. 2017;26(1):1-6. doi:10.1080/09699260.2017.1411421.

5. Lee BH, Inui D, Suh GY, Kim JY, Kwon JY, Park J, et al. Association of body temperature and antipyretic treatments with mortality of critically ill patients with and without sepsis: Multi-centered prospective observational study. Crit Care. 2012;16(1):R33. doi: 10.1186/cc11211. [PubMed: 22373120]. [PubMed Central: PMC3396278].

6. Salgado PO, Silva LCR, Silva PMA, Paiva IRA, Macieira TGR, Chianca TCM. Nursing care to patients with high body temperature: An integrative review. Rev Min Enferm. 2015;19(1):220-6.

7. Young P, Saxena M, Bellomo R, Freebairn R, Hammond N, van Haren $\mathrm{F}$, et al. Acetaminophen for fever in critically Ill patients with suspected infection. N Engl J Med. 2015;373(23):2215-24. doi: 10.1056/NEJMoa1508375. [PubMed: 26436473].

8. Suzuki S, Eastwood GM, Bailey M, Gattas D, Kruger P, Saxena M, et al. Paracetamol therapy and outcome of critically ill patients: A multicenter retrospective observational study. Crit Care. 2015;19:162. doi: 10.1186/s13054-015-0865-1. [PubMed: 25879463]. [PubMed Central: PMC4411740].

9. Gozzoli V, Treggiari MM, Kleger GR, Roux-Lombard P, Fathi M, Pichard $C$, et al. Randomized trial of the effect of antipyresis by metamizol, propacetamol or external cooling on metabolism, hemodynamics and inflammatory response. Intensive Care Med. 2004;30(3):401-7. doi: 10.1007/s00134-003-2087-2. [PubMed: 14722642].

10. Salgado PO, Silva LC, Silva PM, Chianca TC. Physical methods for the treatment of fever in critically ill patients: A randomized controlled trial. Rev Esc Enferm USP. 2016;50(5):823-30. doi:10.1590/S0080623420160000600016. [PubMed: 27982402].

11. Hammond NE, Boyle M. Pharmacological versus nonpharmacological antipyretic treatments in febrile critically ill adult patients: A systematic review and meta-analysis. Aust Crit Care. 2011;24(1):4-17. doi: 10.1016/j.aucc.2010.11.002. [PubMed: 21168342].

12. Cormio M, Citerio G. Continuous low dose diclofenac sodium infusion to control fever in neurosurgical critical care. Neurocrit Care. 2007;6(2):82-9. doi: 10.1007/s12028-007-0002-3. [PubMed: 17522789].

13. Outzen M. Management of fever in older adults. $J$ Gerontol Nurs. 2009;35(5):17-23. quiz 24-5. [PubMed: 19476189].

14. Ryan M, Levy MM. Clinical review: Fever in intensive care unit patients. Crit Care. 2003;7(3):221-5. doi: 10.1186/cc1879. [PubMed: 12793871]. [PubMed Central: PMC270667].

15. Greenberg RS, Chen H, Hasday JD. Acetaminophen has limited antipyretic activity in critically ill patients.J Crit Care. 2010;25(2):3630-7. doi: 10.1016/j.jcrc.2009.07.005.

16. Peacock WF, Breitmeyer JB, Pan C, Smith WB, Royal MA. A randomized study of the efficacy and safety of intravenous acetaminophen compared to oral acetaminophen for the treatment of fever. Acad Emerg Med. 2011;18(4):360-6. doi: 10.1111/j.1553-2712.2011.01043.x. [PubMed: 21496138].

17. Mullins ME, Empey M, Jaramillo D, Sosa S, Human T, Diringer MN. A prospective randomized study to evaluate the antipyretic effect of the combination of acetaminophen and ibuprofen in neurological ICU patients. Neurocrit Care. 2011;15(3):375-8. doi: 10.1007/s12028-011-95338. [PubMed: 21503807].

18. Promes JT, Safcsak K, Pavliv L, Voss B, Rock A. A prospective, multicenter, randomized, double-blind trial of IV ibuprofen for treatment of fever and pain in burn patients. J Burn Care Res. 2011;32(1):79-90. doi: 10.1097/BCR.ob013e3182037300. [PubMed: 21127424]. 
19. Kokki H. Ketoprofen pharmacokinetics, efficacy, and tolerability in pediatric patients. Paediatr Drugs. 2010;12(5):313-29. doi: 10.2165/11534910-000000000-00000. [PubMed: 20799760].

20. Creechan T, Vollman K, Kravutske ME. Cooling by convection vs cooling by conduction for treatment of fever in critically ill adults. Am J Crit Care. 2001;10(1):52-9. [PubMed:11153185].

21. Mayer S, Commichau C, Scarmeas N, Presciutti M, Bates J, Copeland D. Clinical trial of an air-circulating cooling blanket for fever control in critically ill neurologic patients. Neurology. 2001;56(3):292-8. [PubMed: 11171891].

22. Price T, McGloin S, Izzard J, Gilchrist M. Cooling strategies for patients with severe cerebral insult in ICU (Part 2). Nurs Crit Care. 2003;8(1):3745. [PubMed: 12680517].

23. Hoedemaekers CW, Ezzahti M, Gerritsen A, van der Hoeven JG. Comparison of cooling methods to induce and maintain normo- and hypothermia in intensive care unit patients: A prospective intervention study. Crit Care. 2007;11(4):R91. doi: 10.1186/cc6104. [PubMed: 17718920]. [PubMed Central: PMC2206487].

24. Mohammed FA, Ahmed EI. A comparison of vinegar compresses vs. cold water and water with vinegar for treating of fever at tropical hospitals. Int J Nurs Sci. 2012;2(4):38-46. doi: 10.5923/j.nursing.20120204.03.

25. Zeighami R, Haghi M, Kaboudi B. A comparison between the effectiveness of active cooling and sponge cooling in decreasing body temperature of febrile patients in intensive care units. Modern Care J. 2013;10(1):1-9.

26. Zaaqoq AM, Yende S. A touch of cooling may help. Crit Care. 2013;17(2):306. doi: 10.1186/cc12515. [PubMed: 23470248]. [PubMed Central: PMC3672501].

27. Chan EY, Chen WT, Assam PN. External cooling methods for treatment of fever in adults: A systematic review. JBI Libr Syst Rev. 2010;8(20):793825. [PubMed: 27820506].

28. Shah NG, Cowan MJ, Pickering E, Sareh H, Afshar M, Fox D, et al. Nonpharmacologic approach to minimizing shivering during surface cooling: A proof of principle study.J Crit Care. 2012;27(6):746 e1-8. doi: 10.1016/j.jcrc.2012.04.016. [PubMed: 22762936]. [PubMed Central: PMC3494806].

29. Kimberger O, Ali SZ, Markstaller M, Zmoos S, Lauber R, Hunkeler C, et al. Meperidine and skin surface warming additively reduce the shivering threshold: A volunteer study. Crit Care. 2007;11(1):R29. doi: 10.1186/cc5709. [PubMed: 17316456]. [PubMed Central: PMC2151895].

30. Hasday JD, Shanholtz CB, Herold KE. The physiologic and metabolic consequences of external cooling in critically ill patients with fever persisting after treatment with acetaminophen. Intens Care Unit Manage Amer Thorac Soc. 2011:A3154. doi: 10.1164/ajrccmconference.2011.183.1_MeetingAbstracts.A3154.

31. Lenhardt R, Negishi C, Sessler DI, Vuong K, Bastanmehr H, Kim JS, et al. The effects of physical treatment on induced fever in humans. American J Med.1999;106(5):550-5. doi:10.1016/s0002-9343(99)00068-6.

32. Dalal S, Zhukovsky DS. Pathophysiology and management of fever. Support Oncol. 2006;4(1):9-16. [PubMed: 16444847].

33. Launey Y, Nesseler N, Malledant Y, Seguin P. Clinical review: Fever in septic ICU patients-friend or foe? Crit Care. 2011;15(3):222. doi: 10.1186/cc10097. [PubMed: 21672276]. [PubMed Central: PMC3218963].

34. Scaravilli V, Tinchero G, Citerio G; Participants in the International Multi-Disciplinary Consensus Conference on the Critical Care Management of Subarachnoid Hemorrhage. Fever management in SAH. Neurocrit Care. 2011;15(2):287-94. doi: 10.1007/s12028-011-9588-6. [PubMed: 21755388].

35. Johnston NJ, King AT, Protheroe R, Childs C. Body temperature management after severe traumatic brain injury: Methods and protocols used in the United Kingdom and Ireland. Resuscitation. 2006;70(2):254-62. doi: 10.1016/j.resuscitation.2006.02.010. [PubMed: $16828961]$.

36. Thompson HJ, Kagan SH. Clinical management of fever by nurses: Doing what works. I Adv Nurs. 2011;67(2):359-70. doi: 10.1111/j.1365-2648.2010.05506.x. [PubMed: 21044137]. [PubMed Central: PMC3038203].

37. Niven DJ, Laupland KB, Tabah A, Vesin A, Rello J, Koulenti D, et al Diagnosis and management of temperature abnormality in ICUs: A EUROBACT investigators' survey. Crit Care. 2013;17(6):R289. doi: 10.1186/cc13153. [PubMed: 24326145]. [PubMed Central: PMC4057370].

38. Watkins PB, Kaplowitz N, Slattery JT, Colonese CR, Colucci SV, Stewart $\mathrm{PW}$, et al. Aminotransferase elevations in healthy adults receiving 4 grams of acetaminophen daily: A randomized controlled trial. JAMA. 2006;296(1):87-93. doi: 10.1001/jama.296.1.87. [PubMed: 16820551].

39. Howes D, Ohley W, Dorian P, Klock C, Freedman R, Schock R, et al. Rapid induction of therapeutic hypothermia using convectiveimmersion surface cooling: Safety, efficacy and outcomes. Resuscitation. 2010;81(4):388-92. doi: 10.1016/j.resuscitation.2009.12.025. [PubMed: 20122778]. [PubMed Central: PMC2852683].

40. Rodriguez MC. Effects of nursing interventions for fever in acutely ill adults. 1998.

41. Heitman J. Mandell, Douglas, and Bennett's principles and practice of infectious diseases. Mycopathologia. 2000;149(1):47-8. doi: 10.1023/a:1007205402150. 